\title{
COVID- 19 Dental Implications
}

\author{
Farheen Jahan $^{1}$, Rashmi Sapkal ${ }^{2}$ \\ ${ }^{1}$ Dr. Farheen Jahan, Post Graduate Student, Department of Oral Medicine and Radiology, \\ M.A. Rangoonwala College of Dental Sciences and Research Centre, Pune. \\ ${ }^{2}$ Dr. Rashmi Sapkal, Reader, Department of Oral Medicine and Radiology, \\ M.A. Rangoonwala College of Dental Sciences and Research Centre, Pune.
}

\begin{abstract}
This article covers a lot of topic about coronavirus and covid-19 dental implication. Given the wealth of information about coronavirus, this paper attempted to present in different ways. In the first part of this paper, author cover all about coronavirus and in second part, cover dental implications i.e. case selection for dental treatment, before any dental treatment what protocol used in institutions and dental clinics, how to manage staff and students in institutions and dental clinics, treatment wise recommendations and how to manage covid-19 patient either confirmed cases or suspected cases. Lastly,how to change oral medicine and radiology department setup during and after pandemic. What to accept in future and How too little brighter attitude towards this entire pandemic situation.
\end{abstract}

\section{INTRODUCTION}

As you all are aware that coronavirus is not a new virus, which is a virus that existing since more than $5^{\text {th }}$ to $6^{\text {th }}$ decayed, 1960 we had coronavirus, in the past day or couple of days of serious respiratory diseases like SARS and MERS. This virus rights now the disease labeled as COVID-19 or corona virus disease-19, also called as Novel corona virus SARS-COV2. It is highly transmitted virus from one individual to another individuals, but the mortality rate of corona virus is extremely low i.e. ranges to 2 to $5 \%$ of average. It have low mortality rate when compared to SARS \& MERS. WHO announced that corona virus is pandemic on $11^{\text {th }}$ march 2020 and affecting more than 210 countries across the world.

\section{> How The Virus Transmission Starts????}

What is assuming right now, there were some bats in china of particular species? These bats contact with virus and then bats contact with human either in the form of food or in the form of direct contact with the human beings. Once it enters one human host, then it was extremely easy virus to directly go from one human and spread across to a lot of human around. Researchers have been trying a lot of therapeutic modality, a lot of treatment for this some notable one hydroxychloroquine, Remdesivir antiviral again and also tried antibiotics but still don't have promising results from any of them, basically right now we don't have vaccines for corona virus.

\section{MODE OF TRANSMISSION}

When we talk of how this virus transmitted from one person to another, transmission is most commonly in the form of respiratory droplets. These droplets basically released from particular person when infected person coughs or sneezes, also particular person talking a lot of droplets are given out and it may land into mouth of particular person opposite to him or into the eyes, nose. When these virus lands on this surfaces the virus dividing himself, another way this virus can spread by means of fomids that is any inanimate things example person using mobile phone.

Example: The virus is transmitted through the mobile phone when the person was talking and wives take the mobile phone, then she eventually set the virus herself well. These are most common means of transmission of coronavirus. However, there has been a lot of questions about whether this virus is airborne, spread to aerosol or not? Maximum of data available today said that the virus is spread through aerosols. However, airborne transmission from person to person over long distance is unlikely. Even vertical transmission of virus not yet confirmed. (Infected mother to her child)

According to Chan et al 2020 and Rothe et al 2020, modes of transmission from asymptomatic patients and patients in their incubation period are also carrier of SARS COV2. Rothe et al 2020, conclude that uncertain whether patient in the recovering phase are a potential source of transmission of covid-19. The incubation period of covid19 has been estimated at 5to 6days on an average, but there is evidence that is could be as long as 14 days, ( Backer et al) that is the data why advised quarantine period should be approx. 2 weeks (14days).

\section{What Are Symptoms Of Covid-19???}

The most common symptoms are dry cough, which is not very typical with cold. Cold is generally not a symptom of covid-19 situation. Shortness of breath, fever, fatigue most common symptoms seen in corona virus. A person may sometimes have non-respiratory symptoms such as diarrhea, vomiting, headache, muscle pain, confusion, and sore throat. As already discussed that there are also people who are infected with the virus but don't have any symptoms at all. 
Now when we talk about dentistry, there was one article published in Newyork times and eventually adopted times of India as well. They try to tell which professions are at higher risk with covid-19 and at the top one dentist who have very high risk because of expose to oral fluids.

\section{> Why Dentistry Is A Risk Branch???}

Saliva has a pivotal role in the human to human transmission. Also dentist work with aerosols, inhalation of airborne particles and standard protective measures in daily clinical work are not effective enough for fighting the current situation of covid-19.

\section{> How Infection Spread Through Dental Clinic Itself???}

Peng et al 2020 explained the spread of coronavirus from dental practice. If an infected patients walks in clinic, he going to talking, sneezing or coughing these droplets will be airborne, once these droplets are airborne they can direct spread to susceptible individuals. This susceptible individual could be receptionists or other individual of clinic. It is also going to come in contact with equipments and is going to contaminate the equipments. Apart from this, is going to come in contact with other surface of operatory and most importantly dentist are generated a lot of droplets and aerosol in the practice because of which dentist is at higher risk.

\section{KEY RECOMMENDATION FROM INDIAN DENTAL ASSOCAITION}

Additional things are important in practice right now the key recommendation. They have given only treat emergency patients and no other patients. Must avoid treating any patient who has urgent requirements. All elective and scheduled dental procedure must be cancelled and always use adequate personal protective equipment. Avoid all aerosol producing procedures and most important protect yourself, your staff and your patients.

Guideline given by Indian endodontic society, right now we are in the situation, lot of dental patients are giving calls and they are asking as to when the clinic open and I have lot of pain and they know the answer most of clinic are shut. What exactly trouble right now? We need to determined whether patients required emergency care or something not as much as emergency but only required urgent attentions or something that can be postpone that can be classified as scheduled care. Urgent care basically means that, these are those condition where patients are in trouble but try any pharmacological modality to controlling the patient trouble. If the symptoms are not reducing in next few days then need to consider as this patient as emergency patient. Once classified a particular patient as needing emergency, urgent and scheduled care. The next thing classified the patient according to the amount of risk that he carries whether at high risk or low risk patients. Once classified high and low risk then determined what an emergency procedure going to do?? Does the emergency management procedure required aerosol or not?? If not required aerosol then they are safe to perform the emergency management procedure. But if dentist feel that this emergency patient requires aerosol, then try other means or attempts emergency pain relief without producing aerosol. Slow speed micro motor, chemo-mechanical methods to enter pulp chamber; if these are not possible then refer the patient to nearby emergency medical facility for assessment and management.

\section{RISK ASSESSMENTS}

Now we are in lockdown situation almost $2 \frac{1}{2}$ months then do not need to worry about geographical location of the patients. But patient must have surely not travel to any areas which have stage 3 outbreaks. Worry about history of exposure of patient to any suspected patient of covid-19.

\section{$>$ What Is Dental Emergency??}

Dental emergency are those condition, which are life threatening for the patients. Conditions like, uncontrolled bleeding, cellulitis or swelling that potentially compromise the patient airway. Also cases, suffered from facial trauma involving facial bones, potentially compromising the patient's airway. These are dental emergency must be attentive and treated as early as possible.

\section{URGENT DENTAL CARE}

Urgent cares are these by which patients are in trouble right now but try to postpone treatment for few weeks by pharmacological modality. Common urgent dental cares are

- Severe pulpal pain

- Pericoronitis or third molar pain

- Dry socket, dressing changes

- Abscess

- Tooth fracture resulting in pain

- Dental trauma

- Treatment required prior to critical medical procedures

- Final crown cementation if the temporary restoration is lost or broken

- Biopsy of abnormal tissue

- Extensive dental caries causing pain, suture removal

- Denture adjustment on radiation patients

- Repairs when function impeded

- Adjustment of an orthodontic wires

$>$ Routine Or Scheduled Procudere:

- Consultation and recall visit

- Routine scaling

- Preventive therapies

- Orthodontic procedure

- Extraction of asymptomatic teeth

- Restorative dentistry

- Aesthetic dental problems

\section{$>$ Hcq Prophylaxis:}

Any person who health care worker involved in the care of suspected or confirmed cases of covid-19 should take hydroxychloroquine prophylaxis, but could not feel safe by this HCQ prophylaxis. All of us absolutely not taken this medication because of side effects, lot of reservation of HCQ prophylaxis especially cardiac patients, 
retinopathy patients. First confirmed with physicians then start taking medication and HCQ not for children under age of 15 years.

\section{DOSE:}

- Asymptomatic healthcare worker involved in the care of suspected or confirmed cases of covid-19. 400mg twice a day on day 1 , followed by $400 \mathrm{mg}$ once weekly for next 7 weeks, to be taken with meals.

- Asymptomatic household contact of laboratory confirmed cases, $400 \mathrm{mg}$ twice a day on day 1 , followed by $400 \mathrm{mg}$ once weekly for next 3 weeks, to be taken with meals.

D How Should Manage Staff With Respect To Covid-19??

- Actively encourage sick employs to stay home.

- Do not require a health care provider's note for employers who are sick.

- Emphasize respiratory etiquette and hand hygiene by all employers.

- Place hand rubs in multiple locations to encourage hand hygiene.

- Clean all frequently touched surfaces.

- If an employer's is confirmed to have covid-19 informs fellow employers.

\section{PERSONAL PROTECTIVE EQUIPMENTS}

$>$ Mask

$>$ Gloves

$>$ Gowns and caps

$>$ Eye wear

$>$ Face shield.

A. Face Mask Or Respirators:

\begin{tabular}{|c|c|c|c|c|c|c|}
\hline & 3 ply & $\begin{array}{c}\text { FFP- } \\
1\end{array}$ & $\begin{array}{c}\text { FFP- } \\
2\end{array}$ & $\begin{array}{c}\text { N- } \\
95\end{array}$ & $\begin{array}{c}\text { FFP- } \\
3\end{array}$ & N-100 \\
\hline $\begin{array}{c}\text { Respirator } \\
\text { standard }\end{array}$ & - & P1 & P2 & P2 & P3 & P3 \\
\hline $\begin{array}{c}\text { Filtering } \\
\text { rate }\end{array}$ & $30 \%$ & $80 \%$ & $94 \%$ & $95 \%$ & $99 \%$ & $99.97 \%$ \\
\hline
\end{tabular}

Fig 1:- Face mask or respirators.

- Optimizing The Supply Of N-95 Respirators:

$\checkmark$ Extended use: Some respirator for 8-12 hours of continues use.

$\checkmark$ Re-use: Keep aside for minimum 72 hours, preferably 1 week.

B. Eye Protection:

There are two types of eye protection equipments.

$>$ Reusable - clean and disinfect ( silicone type)

$>$ Disposable-discard

Eyewear cover from top, bottom, front and sides that is extremely important and it is suppose to use when entry to the patient's room.
C. Gloves:

Always use fresh gloves upon entry for practice.

$>$ Change the gloves if torn or contaminated.

$>$ Most important immediately perform hand hygiene after removing gloves.

D. Gowns:

Gowns every time worn when enters into the patient's room. It is not necessary for front desk staff to wear a gown at all. Front desk staff should wear respirator, face shield, head caps and pair of gloves. Gowns absolutely mandatory for aerosol producing procedures, when splashes and sprays are anticipated. Gown have minimum thickness about 50$60 \mathrm{gsm}$, and attention should be paid to training and proper donning (putting on) and doffing ( taking off), disposal of any PPE. After that immediate wash hands/ hand hygiene.

\section{Temperature Recording:}

Temperature recording is one of the aspects when patient arrival at clinic or institution, then discussed what patients can treat. It is mandatory to take patient's phone number and address on arrival, because tomorrow local health authority right come to tell that patient suspected or confirmed case of covid-19.

\section{During Visit Of Patients:}

- Once the patient inside the clinic make sure the clinic have sufficient visual signs and alerts because that given to some authority to the assistant taking to them.

- Patient's wash hands first then provides respiratory hygiene and cough etiquette.

- Reception: it is important to cover the entire reception area by installing physical barrier i.e. plastic sheet or plastic glass.

\section{Waitning Room:}

- Provide resources for performing hand hygiene and masks.

- Routine cleaning and disinfection strategies should continue.

- Consider having patients wait in their cars instead of in the waiting room.

- Remove all magazines, toys etc.

- Limit access to the waiting room to patient only.

$>$ Hand Hygiene:

- HCP should perform hand hygiene before and after all patient's contact.

- Before and after contact with potentially infectious material like impression.

- Before putting on and after removing PPE, including gloves performs hand hygiene must. 


\section{PRECAUTION IN OPERATORY}

First and most important is hand hygiene before enter the operatory. Operatory has good ventilation, no AC and should provide PPE for all personnel inside the operatory. Headpiece used must be equipped with anti-reflux device and need to perform 4- handed dentistry technique. Hand piece should be cleaned followed by heat sterilization. It is mandatory to ask the patient to rinse before treated i.e. $1.5 \%$ hydrogen peroxide or $0.2 \%$ providine iodine rinse. Clean and disinfect frequently all operatory surfaces properly and critically maintain a list of dental patient that have been referred to hygiene care department.

\section{$>$ Aerosol:}

Created by: Headpiece, ultrasonic scalers and air water syringes.

Contains: Large particles droplets of water saliva, blood, microorganisms and other debris.

Trajectory: Spatter travel only a short distance and settles out quickly, landing on the floor, nearby operatory surface, dental health care personnel, or the patients.

If AGPs have to be performed:

- Everyone in the room must wear entire PPE.

- No visitor in operatory.

- Only essential HCPs.

- Preferably performed in an airborne infection isolation room (AIIR)

- Dental hand piece with anti-retractive valves.

- Rubber dam.

$>$ Airborne Infection Isolation Room/ Negative Pressure Room:

- Single patient rooms at negative pressure.

- Minimum of 6 air changes per changes per hour.

- Air exhaust.

- Room door should be closed.

Cleaning And Disinfection:

- Mop entire clinic floor with $1 \%$ sodium hypochlorite.

- Disinfect head sensitive equipment with $2 \%$ glutraldehyde.

- Run $0.01 \%$ sodium hypochlorite through hand piece, suction and three-way water lines.

\section{TREATMENTWISE RECOMMENDATION DURING AND AFTER PANDEMIC}

\section{If emergency RCT needs to be performed...}

Whenever you have RCT patient first thing dentist should not come to clinic unscheduled, dentist have to give him the last appointment that is possible of that particular day, because dentist have 10 to 15 hours required to everything settle down, disinfect entire operatory, adequately before any other patients. These procedures should be performed in well ventilated and isolated room. If possible need good quality rubber dam isolation in current situation.

\section{> Chemomechanical Access Opening:}

In this pandemic use enzymatic gel which are available i.e. carie-care, bric 3000 etc. these gel can be put into access cavity to the carious cavity, once it is inside the carious cavity, it starts softening the infected dentine around, leave it inside about 90 secound to $2 \mathrm{~min}$, take a sharp small spoon excavator and try to make ditch. In most cases directly enter into pulp chamber. Just incases could not enter the pulp chamber directly, and then take micromotor of slow speed for access opening, and place arsenic free pulp devitalizer.

\section{Other Treatments:}

- If caries restored as early as possible, then could use silver diamine fluoride to arrest this carious restoration and just place temporary GIC restoration.

- Radiographs- every single article tells don't take intraoral radiographs.

- Absolute don't use ultrasonic scalers.

- Whenever used extraction for a patient as an emergency, make sure to give absorbable suture over the extraction site.

- Only this corona virus time, don't repeat and revisit the patients.

\section{$>$ Dental Treatment Of Covid-19 Patients:}

- Dental treatment of covid-19 suspected or positive patients:

$\checkmark$ Give the patient a respiratory mask.

$\checkmark$ Send the patient home if not an emergency condition

$\checkmark$ Refer the patient to a medical facility if acutely sick.

$\checkmark$ Plan dental treatment in conjunction with medical personnel.

$\checkmark$ Through cleaning and disinfection of entire area.

- Patient with a resolved covid-19 infection:

$\checkmark$ At least 3 days since covid-19 symptoms resolved.

$\checkmark$ At least 7 days since their symptoms first appeared.

\section{DEPARTMENT OF ORAL MEDICINE AND RADIOLOGY}

During and after pandemic, we need to change the department setup (oral medicine and radiology).

As Covid-19 has altered the life style all over the globe even we as Dental Professionals have to alter our protocols for protection of our patients, to prevent spread of COVID-19 and protect ourself.

"Physical Distancing \& Hand Hygiene is The KEY" 
ISSN No:-2456-2165

\begin{tabular}{|c|c|c|c|c|}
\hline Level & AREA & $\begin{array}{l}\text { LOCATION IN THE } \\
\text { DEPARTMENT }\end{array}$ & TEAM MEMEB ERS & $\begin{array}{l}\text { PROCEDURE TO } \\
\text { BE PERFORMED }\end{array}$ \\
\hline Level 1 & Pre-screening area & $\begin{array}{l}\text { At the entrance to } \\
\text { the corridor of the } \\
\text { department }\end{array}$ & $\begin{array}{l}\text { Intern } \\
\text { Staff }\end{array}$ & $\begin{array}{l}\text { 1. COVID } \\
\text { Screening } \\
\text { questionnaire } \\
2 \text {. Temperature } \\
\text { monitoring } \\
\text { through } \\
\text { thermal scanner } \\
\text { 3. Medical } \\
\text { history and } \\
\text { habit history } \\
\text { recording }\end{array}$ \\
\hline Level 2 & $\begin{array}{l}\text { UG CLINIC (OPD } \\
\text { AREA) }\end{array}$ & $\begin{array}{l}\text { Room No } 209 \text { UG } \\
\text { CLINIC }\end{array}$ & $\begin{array}{l}\text { Interns } \\
\text { Hygienist } \\
\text { PGs } \\
\text { Staff }\end{array}$ & $\begin{array}{l}\text { 1. Patient } \\
\text { examination } \\
\text { and diagnosis }\end{array}$ \\
\hline Level & AREA & $\begin{array}{l}\text { LOCATION IN } \\
\text { THE } \\
\text { DEPARTMENT }\end{array}$ & $\begin{array}{l}\text { TEAM } \\
\text { MEMEBERS }\end{array}$ & $\begin{array}{l}\text { PROCEDURE TO } \\
\text { BE PERFORMED }\end{array}$ \\
\hline Level 3 & PG Clinic & $\begin{array}{l}\text { Dept no } .209 \text { PG } \\
\text { SECTION }\end{array}$ & $\begin{array}{l}\text { PGs } \\
\text { Staff }\end{array}$ & $\begin{array}{l}\text { 1. Examination } \\
\text { of } \\
\text { special cases } \\
\text { 2. Medical } \\
\text { Treatment of } \\
\text { oral lesions }\end{array}$ \\
\hline Level 4 & Radiology Clini & No 208 & $\begin{array}{l}\text { PGs } \\
\text { Staff } \\
\text { Technician }\end{array}$ & $\begin{array}{l}\text { 1. Radiographic } \\
\text { examination as } \\
\text { per } \\
\text { Guidelines } \\
\text { (only extraoral } \\
\text { radiographs) }\end{array}$ \\
\hline
\end{tabular}

Fig 1 
Services To Be Provided During Pandemic:

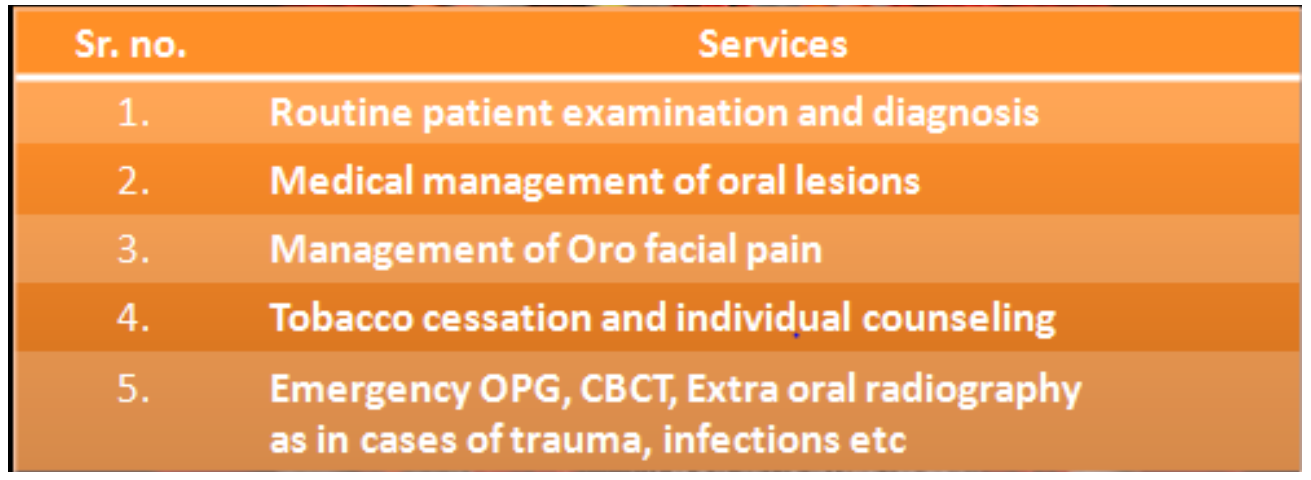

Fig 2

Services To Be Avoided During Pandemic:

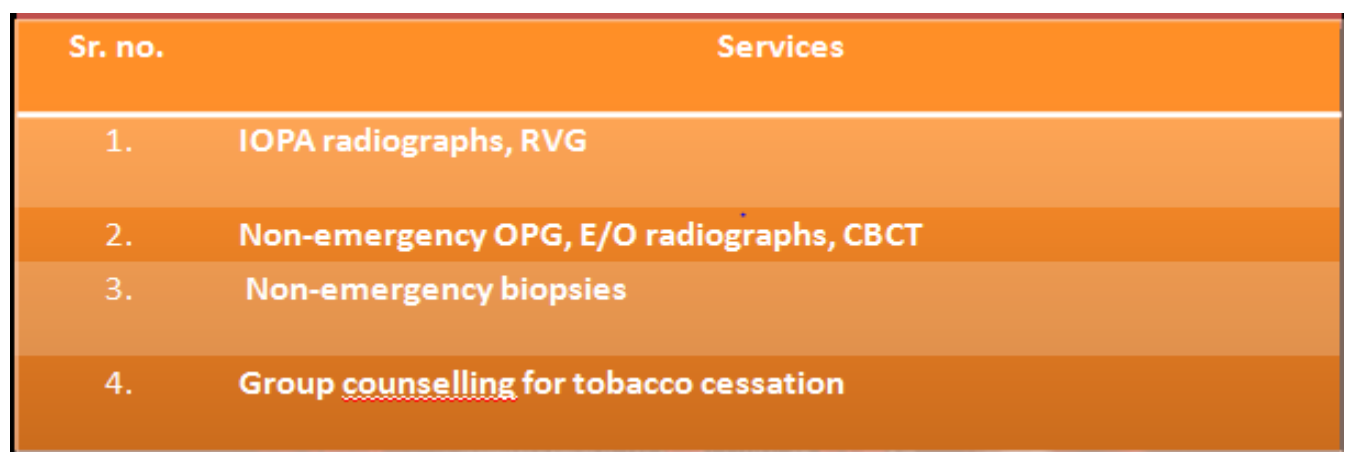

Fig 3

\section{CONCLUSION}

Although in-clinic testing kits exist, they are extremely difficult to obtain. Unless readily available, no one can be assured that they are treating a non-infected individual.

If basic PPE, including surgical facemasks are not available, do not proceed with any dental procedure, regardless of emergency patients.

If a patient with a confirmed diagnosis for covid-19 within the last 14days, who presents with respiratory symptoms, is treated in the dental office, or if any patient is treated without the appropriate PPE, these are considered high risk scenarios. Dentist and members of the dental team should proceed to 14 days quarantine.

\section{ACKNOWLEDGMENT}

Special acknowledges to Mr.Umair khan Patel for constant support and help in completing my research.

\section{REFERENCES}

[1]. Notice from Maharashtra dental council No. NOTICE/21/2020-2021 dated 13/04/2020

[2]. Indian Dental Association's preventive protocol for dental professionals on the corona virus threat.
[3]. CDC Recommendation: Postpone Non-Urgent Dental Procedures, Surgeries, and Visits. Updated: March 27, 2020

[4]. National Guidelines for Infection Prevention and Control in Healthcare Facilities. National Centre for Disease Control, Directorate General of Health Services, Ministry of Health and Family Welfare, Government of India January 2020.

[5]. Centers for Disease Control and Prevention. Transmission of coronavirus disease 2019 (COVID19). Available at: https://www.cdc.gov/coronavirus/2019ncov/about/transmission.html. Accessed 18 March, 2020.

[6]. Sohrabi C, Alsafi Z, O’Neill N, et al. World Health Organization declares global emergency: a review of the 2019 novel coronavirus (COVID-19). Int J Surg 2020;76:71-6.

[7]. Rothe C, Schunk M, Sothmann P, et al. Transmission of 2019-nCoV infection from an asymptomatic contact in Germany. N Engl J Med 2020;382:970-1.

[8]. To KK, Tsang OT, Yip CC, et al. Consistent detection of 2019 novel coronavirus in saliva. Clin Infect Dis 2020. https://doi.org/10.1093/cid/ciaa149.

[9]. Sabino-Silva R, Jardim ACG, Siqueira WL. Coronavirus COVID-19 impacts to dentistry and potential salivary diagnosis. Clin Oral Investig 2020. https://doi.org/10.1007/s00784-020- 03248-x. 10 